\title{
Village Dogs in Coastal Mexico
}

\section{The Street as a Place to Belong}

\author{
Eliza Ruiz-Izaguirre \\ Animal Production Systems Group, Department of Animal Sciences, \\ Wageningen University, the Netherlands; Facultad de Medicina Veterinaria y \\ Zootecnia, Universidad Autónoma de Yucatán, Mérida, México \\ eliza.ruizizaguirre@gmail.com
}

\author{
Paul Hebinck \\ Development and Change, Department of Social Sciences, \\ Wageningen University, the Netherlands; University of Fort Hare, \\ South Africa \\ Karen (C.H.A.M.) Eilers \\ Animal Production Systems Group, Department of Animal Sciences, \\ Wageningen University, the Netherlands \\ Schuttelaar \& Partners, Wageningen, the Netherlands
}

\begin{abstract}
Village dogs are important for households in coastal Mexico, yet they are seen as out of place by etic stakeholders (public health and wildlife experts, and animal welfarists). Caregivers of village dogs are considered irresponsible, a view that is reinforced by Mexican policy. We describe two contrasting etic discourses in this article that have emerged from ideologies based on human-dog relation theories. The article is part of an ongoing shift in the social sciences that has seen attempts to move beyond anthropocentrism and to explore human-animal relations outside the parameters of the traditional nature-culture dichotomy. Local narratives hinge on different experiences with dogs. Villagers perceive their dogs as adults, capable of and subject to judgment. Etic discourses are currently the basis for dog management policies. Attaching the label of "irresponsible owner" to the caregivers of village dogs prevents their inclusion as legitimate participants in policy processes.
\end{abstract}




\section{Keywords}

human-animal relations - village dogs - local narratives - policy discourse

At first I thought they were lost—a gringo assumption I know now. STEEVES, 2005

\section{Introduction}

In the Global North, dogs are popular companions who live inside homes. About $80 \%$ of the dogs in the world, however, can be classified as village dogs (Lord, Feinstein, Smith, \& Coppinger, 2012). Village dogs are typically free-roaming and scavenge refuse around human dwellings (Coppinger \& Coppinger, 2001). Village dogs are local breeds or mixes that are physically quite homogeneous (Ortolani, Vernooij, \& Coppinger, 2009). Over 6o\% of households have dogs in rural areas in Mexico and other countries in the Global South. Human-to-dog ratios range from 1:1 to 5:1, and on average there are two dogs per household (Acosta-Jamett, Cleaveland, Cunningham \& Bronsvoort, 2010; Butler, Du Toit, \& Bingham, 2004; Fiorello, Noss, \& Deem, 2006; Kitala, McDermott, Kyule, Gathuma, Perry, \& Wandeler, 2001; Ruiz-Izaguirre \& Eilers, 2012).

In Mexico, village dogs are called callejeros (street dogs). According to the Mexican Secretary of Health (SSA), the number of callejeros is estimated at 10 million; they account for about $62 \%$ of the Mexican dog population ${ }^{1}$ (SSA, 2001). Village dogs have co-existed with humans for thousands of years. In an increasingly globalized world, contemporary village dogs are, however, no longer part of a local environment with fixed boundaries. Their well-being, treatment, and identity are subjected to a variety of - often sharply contrasting-discourses. These are articulated at different levels of social life and governance, and include etic (the state, NGOs, wildlife agencies) and emic (villagers) discourses. Discourses are relevant to understand how animals, in this case village dogs, are socially constructed and are treated by humans (Stibbe, 2001), and also how they are classified (Buller, 2014).

Public health experts, for example, are concerned with the various risks village dogs pose to human health (e.g., transmission of zoonoses and dog bites)

1 Street dogs in cities, and not only in villages, are included in this number. 
(Matter \& Daniels, 2001), ${ }^{2}$ while wildlife experts are concerned with interactions between village dogs and wildlife, ${ }^{3}$ and governmental authorities are worried about the bad image village dogs give to tourists (Ruiz-Izaguirre \& Eilers, 2012). Tourists to coastal villages see village dogs as too thin and sick, and are concerned about their welfare (Ruiz-Izaguirre \& Eilers, 2012). Tourists are also concerned about acquiring zoonoses (Ruiz-Izaguirre \& Eilers, 2012). Dog-related concerns affect local economies when they become the reasons tourists decide not to return to an area (Fielding, 2008). Despite its lack of social acceptability, culling is the usual method of village dog control. This usually occurs when dog-related problems arise, or there is a special event that will attract many tourists to the area (e.g., football or other sports championships). Animal welfare NGO's are especially concerned about dog culling.

The emic discourses that shape the social construction and treatment of village dogs by local people at the village level have seldom been investigated (Ruiz-Izaguirre \& Eilers, 2012; Bhattacharyya \& Larson, 2014). The aim of this article is twofold: first, to explore the largely ignored and unexplored emic discourses in coastal villages of Mexico regarding village dogs; and secondly, to investigate the etic discourses that sustain current policy regarding village dogs and to compare these with the narratives voiced at the village level. We argue that current policies and attempts to control village dog populations in Mexican villages derive from discourses from the Global North and are largely influenced by human-dog relation theories that are human centered. We link emic and etic discourses to dog domestication theories and argue that these are central to understanding human-dog relations.

\section{Materials and Methods}

We conducted a case study in two rural, coastal villages in which Nahua indigenous communities live and work and dogs are known to cause problems by scavenging sea-turtle nests and begging for food from tourists. The villages are not isolated from global exchanges. They are often visited by tourists, some homes have access to cable television, and young people have access to the Internet in local shops. The villages are situated $30 \mathrm{~km}$ from each other, along

2 Rabies is under control in Mexico; the last human cases were reported in 2000 (SSA, 2001), but it remains highly prevalent in developing communities of Asia and Africa (Morters, Restif, Hampson, Cleaveland, Wood, \& Conlan, 2013).

3 Village dogs can prey on wildlife (Young et al., 2011), act as food competitors with wildlife (Campos et al., 2007), or carry disease to wild canids (e.g., foxes) (Acosta-Jamett et al., 2010). 
the federal road to Lázaro Cárdenas. Colola, with 477 inhabitants (INEGI, 2005), is adjacent to Colola Sanctuary, an important nesting ground for endangered sea turtles (Chelonia mydas, Lepidochelys olivacea). La Ticla, with 415 inhabitants (INEGI, 2005), has a seasonal trade in international tourism, and a capacity to accommodate at least 300 visitors. There is only a little turtle nesting on its beach. No programs have been established to control the dog population in either village.

We visited the villages monthly between June 2008 and June 2009, for four to seven days at a time, in order to observe village dogs and people. We often accompanied the villagers and their dogs to the fields and the beach. Informal talks were held in order to listen to people's narratives about "their" dogs and to hear their memories of them. Twenty-two dog stories were recorded and later transcribed. The narratives were analyzed with a view to understanding how villagers think, feel, and talk about dogs. We wanted to know how animals are included in or excluded from human spaces (Hovorka, 2008; Buller, 2014).

To capture the etic discourses regarding village dogs, we investigated themes related to public health, animal welfare, and damage to wildlife. Our sources included Mexican legislation on dog control; reports of NGO's; scientific and technical articles; newspaper articles; academic articles and chapters in books covering human-dog relationships, and documentary films; websites of animal welfare organizations; and public health websites, such as that of the World Health Organization.

\section{Results}

\section{Etic Discourses}

Keeping dogs only as companions is a relatively recent phenomenon that has resulted from changes in lifestyle and urbanization (Atkins, 2012; Power, 2012). In Mexico, the identity of the callejero did not exist before Spanish colonization or was not widely shared (Valadez-Azúa \& Mestre-Arrioja, 1999). This is very different today. In the global North, companion dogs are commodities with a whole industry (dog food, accessories) attached to them (Haraway, 2008). This model of dog-keeping is now common in urban areas of Mexico too. Companion dogs represent domesticity in contrast to the free-roaming nature of village dogs.

The first discourse identified situates village dogs as vermin who do not belong on the street; village dogs are "out of place" (Srinivasan, 2012; Philo \& Wilbert, 2000), similar to problem pigeons in cities (Jerolmack, 2008) or chickens in African cities (Hovorka, 2008). This discourse is characteristic of wildlife 
agencies and public health authorities (Table 1), and sustains current policy in Mexico. Taking village dogs off the street is rooted in European ideas of domesticity, aesthetics, and sanitation, according to which the social and animal worlds are classified and ordered (Atkins, 2012). These ideas accord with positivist scientific understandings of public health and wildlife ecology. In particular, the fear of rabies has provided a major rationale for the removal of dogs from the streets (Howell, 2012).

The National Commission for Knowledge and Use of Biodiversity (CONABIO) in Mexico classifies dogs as an invasive, exotic species with a high potential for damage (Medellín Legorreta, 200o). This is reflected in the main dog management strategy, which is to eliminate ownerless dogs and vaccinate owned dogs. Due to their large numbers and freedom of movement, callejeros have been accused of being the chief link in the zoonotic chain. They also present the easiest to target for disease control (Malaga-Alba, 1962). Callejeros are categorized as ownerless or as belonging to irresponsible owners (SSA, 2001). The "irresponsible" label is so embedded at the uppermost levels of policy that in the Official Mexican Standard for the prevention and control of rabies, a street dog and the dog of an irresponsible owner are categorized in the same way (SSA, 2011). The Mexican department of health (SSA) captures dogs on the streets and takes them to the antirrábicos (dog pounds), where they are killed. The ssA, however, does not have enough resources or infrastructure to work in rural areas, where redadas (dog raids) are resorted to instead. The local authorities capture and kill dogs or put out poisoned bait for them (Ruiz-Izaguirre \& Eilers, 2012).

The second type of etic discourse we have identified portrays village dogs as victims, and is characteristic of animal welfare organizations (Table 1). Mexican village dogs are perceived as being too thin or sick. The methods for trapping and killing village dogs (e.g., by electrocution) concern international animal welfare organizations (Buchanan, 2007), which raise funds for dogs in countries in the Global South (Falconer, 2009). The funds aim to help those "emaciated dogs sleeping on rubbish piles, injured dogs limping across market squares, and dogs so afflicted with mange they're basically scratching themselves to death" (Falconer, 2009, p. 14).

The animal welfarist discourse is compatible with theories that describe the human-dog relation in terms of the relationship between a parent and child (Burgess-Jackson, 1998; Hens, 2008; Power, 2012; Blouin, 2013). Unlike children, though, dogs never grow into completely autonomous beings who are able to make their own choices (Hens, 2008). In terms of this perspective, village dogs 
TABLE 1 Differences and similarities of etic discourses

\begin{tabular}{|c|c|c|c|c|}
\hline Issue & $\begin{array}{l}\text { Animal } \\
\text { welfarists }\end{array}$ & $\begin{array}{l}\text { Public health } \\
\text { experts }\end{array}$ & Wildlife experts & Villagers \\
\hline $\begin{array}{l}\text { Perceptions } \\
\text { about village } \\
\text { dogs }\end{array}$ & $\begin{array}{l}\text { Victims in } \\
\text { need to be } \\
\text { rescued }\end{array}$ & Vermin & Vermin & $\begin{array}{l}\text { Non-human } \\
\text { animals with the } \\
\text { capacity to judge } \\
\text { in adulthood }\end{array}$ \\
\hline $\begin{array}{l}\text { Acceptance of } \\
\text { dogs on the } \\
\text { street }\end{array}$ & Yes/No & No & No & Yes \\
\hline Concerns & $\begin{array}{l}\text { Poor dog } \\
\text { welfare }\end{array}$ & $\begin{array}{l}\text { Zoonoses, dog } \\
\text { bites }\end{array}$ & $\begin{array}{l}\text { Wildlife } \\
\text { predation }\end{array}$ & $\begin{array}{l}\text { Stealing of food, } \\
\text { dog bites }\end{array}$ \\
\hline Site-specific & $\begin{array}{l}\text { Urban and } \\
\text { rural }\end{array}$ & $\begin{array}{l}\text { Urban and } \\
\text { rural }\end{array}$ & Rural & Rural \\
\hline $\begin{array}{l}\text { Current } \\
\text { solutions }\end{array}$ & $\begin{array}{l}\text { Adoption, } \\
\text { surgical } \\
\text { sterilization, } \\
\text { Animal Birth } \\
\text { Control (ABC) } \\
\text { programs }\end{array}$ & $\begin{array}{l}\text { Methodical } \\
\text { culling }\end{array}$ & $\begin{array}{l}\text { Methodical } \\
\text { culling }\end{array}$ & $\begin{array}{l}\text { Non-methodical } \\
\text { culling }\end{array}$ \\
\hline $\begin{array}{l}\text { Perceptions } \\
\text { about village } \\
\text { dog caregivers }\end{array}$ & Irresponsible & Irresponsible & Irresponsible & $\mathrm{N} / \mathrm{A}$ \\
\hline $\begin{array}{l}\text { Compatibility } \\
\text { to human-dog } \\
\text { theories }\end{array}$ & $\begin{array}{l}\text { Protectionist } \\
\text { or humanistic } \\
\text { orientation } \\
\text { response- } \\
\text { ability }\end{array}$ & $\begin{array}{l}\text { Domination } \\
\text { orientation }\end{array}$ & $\begin{array}{l}\text { Domination } \\
\text { orientation }\end{array}$ & $\begin{array}{l}\text { Independent } \\
\text { materiality }\end{array}$ \\
\hline $\begin{array}{l}\text { Characterization } \\
\text { of relation }\end{array}$ & $\begin{array}{l}\text { Parent-child, } \\
\text { friend-friend, } \\
\text { response- } \\
\text { ability }\end{array}$ & Vermin & Vermin & $\begin{array}{l}\text { Boss-worker, } \\
\text { friend-friend, } \\
\text { Response-ability }\end{array}$ \\
\hline $\begin{array}{l}\text { In line with } \\
\text { human-centered } \\
\text { theory on dog } \\
\text { domestication }\end{array}$ & Yes & Yes & Yes & No \\
\hline
\end{tabular}


appear as abandoned and in need of rescue. ${ }^{4}$ Battaglia and Saldarriaga (2011) show in their documentary that the perception of village dogs as abandoned appears at the highest levels of international policy. Mexico City is in the forefront of animal welfare at a national level; its legislation is the basis for legislation in other Mexican states. Under Mexico City's animal welfare law, a dog on the street without his/her owner is categorized as "abandoned" (Asamblea Legislativa del Distrito Federal II Legislatura 2002, definitions). If the dogs are considered abandoned in this way, those who abandon them are automatically rendered irresponsible.

According to the World Organization for Animal Health, a person who owns a dog is responsible to take lifetime care of the dog and his/her offspring, unless another owner is found. The owner has to ensure that "the dog does not roam in a manner that would pose a problem for the community and (or) the environment" (OIE, 2011, p. 3). This definition of responsibility is consistent with the way in which wHO classifies dogs in terms of their dependence on humans: restricted dogs, family dogs, community dogs or feral dogs (wHO, 1988). As Ortolani et al. (2009) note, though, this classification takes for granted that all dogs are or have been owned by humans, which is not the case in the Global South. Furthermore, the human-dog relationship is not a stable one (Power, 2012).

Many of the conflicting ideas about human obligations towards dogs arise from ethical considerations rooted in human-dog relation theories. Domestication theories elucidate both early and current human-dog relations. The popular human-centered theory about dog domestication ${ }^{5}$ presumes that humans played the major role in dog domestication (Coppinger \& Coppinger, 2001). The underlying assumption of this theory is that humans should assume full responsibility for dogs since they created them in the first place. Providing homes for "helpless pets" is "a burden of responsibility on us humans since to a great extent we created pets" (Fox, 1980, p. 81).

4 See for example, Haraway (2003, p. 88) and initiatives to import village dogs from Mexico and Puerto Rico to the U.s.A. (Strand, 2003), or from Thailand to countries throughout the world (Soi Dog Foundation, 2012).

5 The human-centered theory hypothesizes that about 150,00o years ago, human hunters must have killed wolves for skin and meat, occasionally taking their pups, who became tame. When there were enough tame wolves in the human settlement, breeding resulted in a next generation of even tamer wolves. Over many generations, wolves transformed into dogs (see Clutton-Brock, 1995). 
Coppinger and Coppinger's (2001) alternative theory of dog domestication ${ }^{6}$ argues that it was not humans who took dogs from the wild, but dogs (i.e., wolves) who decided to enter human territory to exploit a new niche: the village dump. Ethical considerations based on this theory do not consider village dogs as abandoned because they were never adopted as in-house residents in the first place. Dogs in this theory are recognized as agents and co-producers in their domestication. Power (2012) maintains that domestication is not a finished state, but must be continuously negotiated and held in place. Dogs are neither pure nature nor cultural constructs. They can be better described as nature-cultural beings (Haraway, 2003; Hens, 2009).

\section{Emic Discourses: Case Study in Coastal Villages}

Emic discourses are produced at the village level by the caregivers of village dogs who interact in everyday life with them. It is these discourses that are not heard and voiced at the public-policy level.

Along the Nahua Coast of Michoacán, most people subsist on small-scale tourism and agriculture. The main crops are corn (Zea mays), papayas (Carica papaya), and tomatillos (Physalis ixocarpa). Animals kept for consumption include pigs, poultry, and cows. In an excursion to the mountain and coastal areas in 1950, Brand (1960) noted that indigenous people's only companion animals were dogs and parrots. In the villages, dogs are mobile delimiters of space and property for other dogs, animals, and people - they guard the solar ${ }^{7}$ and farm fields, for example. And in places where the main means of transportation is walking, dogs are naturally inclined to follow people around the village.

Dog-keeping practices were similar in both the farming (Colola) and tourist (La Ticla) villages (Table 2). Caregivers in both villages allowed their dogs to roam free and occasionally tethered them to correct unwanted behavior. In both villages, dogs interacted with men, women, and children, and women

6 The dumps of the first human settlements created a new niche that could provide a regular supply of food year-round for wolves who scavenged around human settlements. A process of natural selection occurred. Wolves who were less afraid of humans could scavenge (search for food) and continue eating in proximity to humans. Small body size, teeth, and brains were an adaptive advantage in the village niche. Smaller brains required less energy, which wolves no longer needed for hunting in packs (see Coppinger \& Coppinger, 2001).

7 The solar is the typical rural household consisting of a house, surrounded by a garden with trees, plants, and domestic animals. The solar is usually delimited (with sticks or branches) but not fenced. 
TABLE 2 Comparison of dog-keeping characteristics in two villages

\begin{tabular}{lll}
\hline Issue & Tourist village & Farming village \\
\hline Openly concerned about dog breeding & & Yes \\
Preference for male dogs & Yes & Yes \\
Culling of female pups & Yes & Not apparent \\
Concerned about unwanted dog behavior & Yes & Yes \\
Tethering used to correct dogs & Yes & Yes \\
Hanging occurred for biting dogs & Yes & Yes \\
Dogs fed daily & Yes & Yes \\
Poisoning of dogs occurred during study period & Yes & No \\
Male farmers were especially fond of working dogs & No & Yes \\
(male or female) & &
\end{tabular}

were responsible for feeding them. There was a marked preference for male dogs in both villages. Breeding females caused problems. Luis, a 10-year-old boy from the farming village, brought Chispa home as a pup and told his mother she was a male. When the mother found she was a female, she tried to get rid of the dog. Chispa returned twice, though, and finally remained in the household.

\section{Dog Functions and Relations with Men, Women, and Children}

Male farmers from the farming village were especially fond of working dogs, both male and female (Table 2). Farmers remembered working dogs who had died many years ago. The dogs' work was not very specialized but did require some training, which not everybody was willing to give. According to some of the men, "good dogs are scarce," and pedigree dogs were better than plain village dogs. Villagers referred to pedigree dogs as finos (fine, special), pura sangre (pure blood), sangre especial (special blood), or de clase (high class). The common village dog was called criollo (mixed; used in colonial times to describe a Spanish and Indian mix), or corriente (common and of little value). According to Erasmo, one of the villagers, "Any dog could be trained to guard if you started taking the dog as a puppy to the fields." Another villager, Antonio, maintained that: "You need to have patience to teach animals to work in the fields ... it is just like us, if I call you 'hey stupid,' and I treat you with anger, you will ask yourself why I treat you like this, but if I ask you kindly, of course you do [the work]." 
Dogs were required to protect the household and farm fields, to chase away animals like donkeys, to help catch iguanas, and sometimes to gather backyard chickens for slaughter. Villagers left their belongings unattended on the beach or in the fields, knowing that the dogs would protect them. Dogs were left to guard the fields during the night or during the most vulnerable periods of the day. Dogs chased away parrots or other animals who wanted to eat the crops. The dogs, though, had the run of the fields and could also leave whenever they wanted to:

As dawn was breaking, what did she do? She threw herself loose in the fields, and when she found her [dog] friend, she would take her along ... [Then she had puppies.] She took really good care of the little animals, and I was very fond of my dog because she was very well behaved and she would do all the jobs I would put her to do. Only and only that she then ... chased an animal down a hill, I just heard her barking, right? Well, she just never came back. Like they say: We never met Mónica again ... I think that animals killed her, maybe a jabalí [wild swine].

ANTONIO, FARMING VILLAGE

Antonio acknowledged Mónica's freedom to decide where she wanted to go, and also her ability to care for herself and her pups. This autonomy entailed some risks. She might be killed by wild swine, for example. Antonio and Mónica met every day, not in a parental relation (i.e., father-child), but as equals.

Village dog-keeping allowed for a certain flexibility in accommodating dogs in households, depending on the character and preferences of the dog. When a village dog "arrives" in a household, the caregiver might send the dog away, but the dog might also come back. A dog may also choose to live in another household. Many of the dogs from Noemís household in the tourist village did not want return once they found the way into her mother-in-law's house. The mother-in-law recalled: "You take pups from here, and it is useless, they always come [back] and stay here." A family member may not consider a dog useful, but this is not the end for the dog. Erasmo spoke of his current dogs: "These (dogs) are not useful to me for anything, just barking and barking." This view was not shared by Erasmo's wife. Dogs protected her backyard chickens and were trained to collect them for her.

Women also enjoyed dogs for their company. Petra often walked in the afternoons to the farm fields of Colola (about two kilometers) to get firewood to cook or to pick fruit like mangoes and lemons. She was eager to demonstrate how her dogs stood up excitedly and were ready to go as soon as they saw her lifting up her machete. The neighbor's dog also came along. They would run 
off during the walk and then return to her. Village dogs were also kept as bodyguards for children:

If you put this dog to work (cuichili cuichili ${ }^{8}$ ) or if you start to talk a bit louder, what does this dog do? She lies down and closes her eyes [with her paws] like this, she huddles like this, she thinks I am scolding her ... it is better for her to be the children's companion, she follows them, but not me.

ANTONIO, FARMING VILLAGE

Women mentioned that dogs took care of their husbands when they got drunk, following them and escorting them home. Amanda, the wife of a farmer was surprised at how much their dog cared for her husband. Villagers often talked about their dogs' affection, using the word ingriar. ${ }^{9}$ They recognized how dogs get excited greeting specific humans, explicitly manifesting this with their bodies.

I think that animals also, who knows what they think, are they maybe the same as Christian men? Only because they do not talk, right? They do feel the same, or? ... I do not know why the dog grew [so] fond of him.

AMANDA, FARMING VILLAGE

\section{Unwritten Rules}

At first sight, there was no regulation of dogs in the villages. We nevertheless gradually discovered that unwritten codes of conduct existed even though it was socially acceptable for dogs to roam free. Dogs were expected to behave well, not only at home, but also with neighbors. Dog caregivers were generally permissive and neighbors tolerant, but this tolerance had a limit. In general, dog-related problems (for the caregiver or for neighbors) were from unwanted dog behavior - for example, aggression (i.e., dogs who bit, fought with other dogs, or chased people). Mischievous dogs who stole food or killed poultry were also a problem. Biting people was taken very seriously. According to villager narratives, dogs could exercise judgment and were, therefore, responsible for their actions: "That depends on us, if one teaches them, they also

8 This is the way he calls his dog when he wants him to go and chase away animals.

9 Ingriar or engriar comes from the verb engreír, which according to the Real Academia Española (2017) means: encariñar, aficionar. In our stories, the verb appears mostly conjugated with dogs, less often with humans. We understand this as a preference and loving of a specific human on the part of the dog, and our best English translation is "growing fond of." 
learn how to.... It seems as if they didn't have judgment, ${ }^{10}$ but they do have judgment" (Andrea, tourist village).

Guillermina, who lives in the tourist village, recalls how her dog used to bite people. She tried to correct his behavior by tethering him for a few days, but once he was free again: "He had no pity." The dog was hanged after he bit a young girl. Similarly, María's dog, Rallado, was given another chance after he bit a young man. But when he bit the neighbor's boy:

We got him, he scratched and pulled the rope, we wanted to let him loose, but then, no, he will bite again, we better kill him, and we pulled hard on his neck, and he died.

MARÍA, FARMING VILLAGE

The children cried. Rallado used to accompany them to the farm fields and helped them catch iguanas and cuichis (small squirrels). However, it was likely that Rallado would bite someone again and that a payment would have to be made to the victim's family. In any event, when caregivers refuse to kill dogs themselves, the neighbors usually poison the dogs.

\section{Caregiving}

Caregivers in the villages gave the dogs tortillas with meat broth every day, and often fish and meat leftovers as well. Dogs received food from one or more households, but most dogs also scavenged for extra food. They also hunted iguanas and squirrels, and ate sea-turtle eggs. An old lady wondered how her female dog was in such good condition that she could fall pregnant even though she only got a few tortillas a day. The dog used to find food herself. This was a quality that the old woman admired: "My little dog was a fighter."

Common medical problems for village dogs included mange, scorpion bites, pneumonia, road accidents, and poisoning. In the absence of veterinary services, villagers had to deal with sick, unwanted, or unsuitable dogs themselves. The nearest veterinarian was $200 \mathrm{~km}$ away. Angela tried every known treatment to cure her dog Pinto of mange: bathing the dog in the sea, giving herb infusions, applying ointments with burned oil, and diesel. As a last resort, she began saving to buy chlorine, which her friend used to cure her dog. If this did not work, she would have to kill the dog. ${ }^{11}$ Other local remedies included

10 Translation of juicio, which according to the Real Academia Española (2017) is defined as: faculty of the soul, by which man can distinguish good and bad, true and false.

11 Finally, this did not happen. Her son brought her a dewormer on a trip to the city and Pinto was cured. 
lemon necklaces for pneumonia and olive oil for poison. Villagers acknowledged the capacity of dogs to ask for help: "I was sitting there, the dog came to me, he touched me, I think he wanted my attention, let us say, he was talking to me" (Martín, farming village).

Caregivers responded to their dogs' needs as best they could. Dealing with dog breeding, however, sometimes presented a problem (Table 2). Pups were easier to place in the farming village because of its proximity to the mountains where dogs are wanted for farming.

People come and say: 'oh your dog has puppies! Can I have one?' ... [he answers] Of course! And they take them, that's why I have no worries about her [Paloma] being female.

MARIANO, FARMING VILLAGE

In the tourist village, however, things were different. Guillermina explained that everyone knew that it was not a sin to drown pups as soon as they are born, just before they started nursing. Nevertheless, at least in her case, she experienced much guilt and anxiety about this. She recalled how she got "a punishment from God." Her three female dogs gave birth at the same time: "Only female puppies, oh my God!" She passed each pup as they were born to her daughter to verify the sex. Then they killed them. But when they went to the beach to get rid of the corpses, they discovered that the puppies were males after all. Guillermina panicked and started crying. She promised San Lázaro ${ }^{12}$ that she would never kill a dog again.

\section{Discussion}

\section{Discourse Interactions and Controversies}

On Responsibility

According to Mexican policy and international legislation, caregivers of village dogs can be categorized as "irresponsible owners." This categorization represents an obstacle to finding alternative solutions to village dog-related problems. Unheard voices cannot, as McGee (2004) and Long (2001) point out, exercise agency in policy processes. Furthermore, the label irresponsible

12 He is not a canonized saint, but popular in Mexico and Cuba. Lázaro is mentioned in a parable in the book of Luke. He is portrayed as a poor, old, and sick man with dogs licking his sores. Some people believe he is the protector of dogs. 
entails a moral judgment. Burgess-Jackson (1998) argues that humans limit animals' opportunities to fulfill their own needs and generate dependence when they let animals live in the home. They then become responsible for the animal. This argument fits the prevalent situation of dogs in the Global North. Village dogs are a different matter. What does human responsibility mean when dogs are not prevented from meeting their needs themselves in a place where they can still "be in the absence of a human owner" (Srinivasan, 2012, p. 5)?

Steeves (2005) points out that we should question the way we define care and home; "the neighborhood can be a home, a place to belong" (p. 22). In fact, villagers do care about dogs, and are able to respond to their needs, albeit not in the way in which the OIE (2011) defines responsibility. Rather they act more in accordance with what Brown and Dilley (2012) term response-ability. People and dogs exhibit the ability to mutually demand and enable responses. When a village dog demands food or attention, the caregiver is able to respond (Table 1).

In terms of Blouin's (2013) owner dimensions, the diversity of human-dog relations found in the study site ranges from boss-worker to friend-friend (Table 1). The boss-worker relationship is qualified by the fact that villagers only take advantage of dogs' natural abilities as agricultural helpers. The dogs can leave whenever they wish or decide not to work at all. These relations are generally based on trust, which, according to Hens (2009), is a major component of human-dog relationships. The extreme relationships found between people and dogs in the Global North, such as the boss-slave or parent-child relationships described by Blouin (2013) are largely absent (Table 1).

There is a growing rejection within the social sciences of anthropocentrism as the starting point for understanding human dealings with animals (Wolch \& Emel 1998; Buller 2004; 2014). Villagers possess a perception of dogs that can be described in terms of an ecology of difference rather than in traditional anthropocentric categories (Escobar, 1998). They recognize the "independent materiality" (Buller, 2004) of dogs, a recognition that lends credence to the theory of village dog domestication described earlier (Table 1). Unlike the idea that dogs are like children who never grow up (Hens, 2008), villagers perceive (grownup) village dogs as adults. They are capable of caring for themselves and others (children, drunk men, domestic animals), capable of decision making, capable of asking for help when needed, and both capable of and subject to judgment.

Dogs are guardians of the family. The dangers of roaming on the street should not be downplayed though. The difficult economic circumstances in our study 
sites and a serious lack of veterinary services present caregivers with dilemmas in their relationships with dogs. They sometimes have to resort to hanging or drowning unwanted or sick dogs. Nevertheless, the caregivers assume responsibility for difficult decisions that can cause considerable distress for both the dogs and the children and adults of the household.

\section{Public Health and Wildlife Protection}

In terms of policy, village dogs fall in a grey zone between the wild and the domestic. Like wild ungulates in nature areas, for example, they do not fall into a neat category (Gamborg, Gremmen, Christiansen, \& Sandoe, 2010). The Global South often looks to the North for models (e.g., India towards the United Kingdom) (Srinivasan, 2012). It is not surprising, therefore, that developing countries such as Mexico base policies on human-dog relation models that are prevalent in the Global North. Nevertheless, removing village dogs from the street is costly and logistically unattainable in rural areas in Mexico. Such a move would require changes in lifestyle, culture, and infrastructure - property would have to be fenced, for instance. Dogs would then have to be provided with the food that they now scavenge for themselves.

Furthermore, it is culturally acceptable for dogs to roam free in the villages. The dogs also fulfill useful functions as guardians and companions. Policies, particularly those that are designed in a top-down manner, can seldom be translated directly into action because they are bound to conflict with narratives and practices that contradict them (Long, 2001). Insisting on the letter of law can have unintended consequences. Many dogs, for example, are permanently tethered or kept on the rooftop in Mexican cities because dogs are not allowed to roam free.

We propose that etic discourses that stem from a public health or wildlife perspective need to be critically evaluated in village settings. There is, for example, less chance of zoonoses transmission (e.g., through dog feces) in places with plentiful space than there is in crowded cities (Acosta-Jamett et al., 2010). The villagers in our study did not mention having problems with dog feces. Generally, dogs defecate in the bushes. Unlike in the cities, most village dogs are associated with specific households (Acosta-Jamett et al., 2010), and are accessible for prophylaxis (Butler \& Bingham, 2000; Morters, Bharadwaj, Whay, Cleaveland, Damriyasa, \& Wood, 2014). The fact that most village dogs are associated with a household from which they receive daily food helps protect wildlife. Relatively simple solutions such as nightly tethering or increasing food intake decrease the chance that the dogs will go out scavenging sea-turtle nests (Ruiz-Izaguirre, Woersem, Eilers, Wieren, Bosch, Zijpp, \& Boer, 2014). 


\section{On Co-Existence}

According to Coppinger and Coppinger (2001), village dogs are the missing link between the wild and the domestic. At present, village dogs co-exist with humans as agents. Both find a place in the village. Etic discourses often highlight the negative aspects of village dog-keeping and ignore the positive aspects. Dogs have freedom of mobility in a village setting (Donaldson \& Kymlicka, 2011). They have space in which to wander and can select their companions, human or non-human. Placing a dog in a particular household is only the beginning of a dog's life history; staying with the household is beyond human control. The dog might stay or choose another household through establishing particular kinds of affective and convenience relations with humans. Furthermore, dogs have socio-cultural roles; they are important to the community as a whole (Constable, Dixon, \& Dixon, 2010).

Village dog breeding remains a difficult aspect of dog-human co-existence. According to animal welfarist discourses, humans are responsible for controlling dog populations through sterilization. However, some reproduction is necessary for village dogs to survive. Dogs, after all, are also needed by people. Selective sterilization of female dogs, such as that described by Di Nardo, Candeloro, Budke, \& Slater (2007), may be compatible with emic perspectives. Culling is the only option in the absence of resources for sterilization. This is done in a non-systematic way, either by drowning female puppies or by angry neighbors who put out poison bait. Drowning controls the dog population but is ethically questionable. Poisoning ends up killing not only the targeted dogs but also dogs who have no behavioral problems. Culling healthy adult dogs does not solve anything because those dogs are rapidly replaced. New dogs arrive themselves or are introduced by people shortly after a cull (WHO, 1998). There is both a need for humans to have dogs and also a niche to sustain them. Significant evidence also exists that shows that culling is an ineffective way of controlling rabies and other zoonoses (Morters et al., 2013). Culling is a quick solution that ignores the complexities of village dog-keeping.

From a modern, ethnocentric perspective, village dogs might appear lost or abandoned (Steeves, 2005; WSPA, 2012). But in fact, the proportion of dogs with truly no association with humans (i.e., feral dogs) or not cared for by humans (truly abandoned or lost) is less than 10\% (Matter \& Daniels, 2001). The majority of village dogs associate with one or more households (Boitani, Ciucci, \& Ortolani, 2007), which provide them with different levels of care (e.g., food, shelter, veterinary care). Strong affective bonds exist between the dogs and these households. 


\section{Conclusion}

Village dog-keeping generates ambiguities and issues that cannot be easily resolved. Etic discourses are currently the basis for dog management policies. The label of "irresponsible owner" in dog management policies prevents the actual caregivers of village dogs from acting as legitimate participants in policy processes. Furthermore, basing policy only on dominant etic discourses denies the recognition of the possibility that this way of dog-keeping is a legitimate way of relating to and living with dogs, with its own drawbacks and benefits. Although dogs do not live inside the home, they still play an important role for the household. Dogs' everyday interests - chasing animals away and protecting the family - are accommodated in human-dog relationships.

Understanding how human-dog relation theories play a role in ethical considerations about village dogs could be useful for both policy-makers and villagers. It could help people to understand different points of view and stimulate discussions about village-dog management. Village-dog-keeping is not a failed version of the sort of dog-keeping that is found in the Global North. Cultural, ecological, and socio-economic factors come together in this form of dog-keeping. Not acknowledging village-dog-keeping as legitimate has often resulted in partial, unsustainable, foreign-imposed "solutions" and mass killings of village dogs.

\section{Acknowledgments}

We are grateful to all the villagers who shared their dog stories and experiences at Colola and La Ticla villages. The first author was funded by The Council for Science and Technology of Mexico (doctoral scholarship) and the Alfa en Omega Stichting. The first author gratefully acknowledges the Animal Studies Institute-Wesleyan Animal Studies for sponsoring a summer scholarship. We thank Imke de Boer and Akke van der Zijpp for their thoughtful comments on an earlier version of the manuscript, and Michael Wessels for English editing. The views expressed in this article do not necessarily reflect the opinions or positions of the sponsors.

\section{References}

Acosta-Jamett, G., Cleaveland, S., Cunningham, A., \& Bronsvoort, B. (2010). Demography of domestic dogs in rural and urban areas of the Coquimbo Region of Chile and implications for disease transmission. Preventive Veterinary Medicine, 94(3), 272-281. 
Asamblea Legislativa del Distrito Federal II Legislatura. (2002). Ley de Protección a los Animales del Distrito Federal.

Atkins, P. (2012). Animal Cities: Beastly Urban Histories. Farnham, United Kingdom: Ashgate Publishing.

Battaglia, D., \& Saldarriaga, A. (2011). Why Is Dog Population Management Important? (Documentary). Animal Production Division and Health, Food and Agriculture Organization of the United Nations (FAO). Retrieved from www.fao.org/ag/againfo /resources/en/videos_AW.htm.

Bhattacharyya, J., \& Larson, B. M. (2014). The need for indigenous voices in discourse about introduced species: Insights from a controversy over wild horses. Environmental Values, 23(6), 663-684.

Blouin, D. D. (2013). Are dogs children, companions, or just animals? Understanding variations in people's orientations toward animals. Anthrozoos: A Multidisciplinary Journal of the Interactions of People \& Animals, 26(2), 279-294.

Boitani, L., Ciucci, P., \& Ortolani, A. (2007). Behaviour and social ecology of free-ranging dogs. In P. Jensen (Ed.), The Behavioural Biology of Dogs (pp. 147-165). Wallingford, UK: CAB International.

Brand, D. (1960). Coalcomán and Motines del Oro: An Ex-distrito of Michoacán Mexico. University of Texas at Austin. Institute of Latin American Studies.

Brown, K., \& Dilley, R. (2012). Ways of knowing for 'response-ability'in more-thanhuman encounters: The role of anticipatory knowledges in outdoor access with dogs. Area, 44(1), 37-45.

Buchanan, B. (2007). Companions to None: A Documentary Film (DVD). Buchanan Film Company.

Buller, H. (2004). Where the wild things are: The evolving iconography of rural fauna. Journal of Rural Studies, 20(2), 131-141.

Buller, H. (2014). Animal geographies I. Progress in Human Geography, 38(2), 308-318.

Burgess-Jackson, K. (1998). Doing right by our animal companions. The Journal of Ethics, 2, 159-185.

Butler, J. R. A., Du Toit, J. T., \& Bingham, J. (2004). Free-ranging domestic dogs (Canis familiaris) as predators and prey in rural Zimbabwe: Threats of competition and disease to large wild carnivores. Biological Conservation, 115(3), 369-378.

Butler, J. R., \& Bingham, J. (200o). Demography and dog-human relationships of the dog population in Zimbabwean communal lands. The Veterinary Record, 147(16), 442-446.

Campos, C., Esteves, C., Ferraz, K., Crawshaw, P., \& Verdade, L. (2007). Diet of freeranging cats and dogs in a suburban and rural environment, south-eastern Brazil. Journal of Zoology, 273, 14-20.

Constable, S., Dixon, R., \& Dixon, R. (2010). For the love of dog: The human-dog bond in rural and remote Australian indigenous communities. Anthrozoos: A Multidisciplinary Journal of the Interactions of People \& Animals, 23(4), 337-349. 
Coppinger, R., \& Coppinger, L. (2001). Village dogs. In R. Coppinger \& L. Coppinger (Eds.), Dogs: A New Understanding of Canine Origin, Behavior and Evolution (pp. 6982). New York, NY: Scribner.

Di Nardo, A., Candeloro, L., Budke, C. M., \& Slater, M. (2007). Modeling the effect of sterilization rate on owned dog population size in central Italy. Preventive Veterinary Medicine, 82(3), 308-313.

Donaldson, S., \& Kymlicka W. (2011). Zoopolis: A Political Theory of Animal Rights. New York, NY: Oxford University Press.

Escobar, A. (1998). Whose knowledge, whose nature? Biodiversity, conservation, and the political ecology of social movements. Journal of Political Ecology, 5(1), $53-82$.

Falconer, J. (2009.) Slum dogs by the millions. All Animals Magazine, September, 12-19.

Fiorello, C. V., Noss, A. J., \& Deem, S. L. (2006). Demography, hunting ecology, and pathogen exposure of domestic dogs in the Isoso of Bolivia. Conservation Biology, $20(3), 762-771$.

Fox, M. W. (1980). Pets and their owners. In Returning to Eden. Animal Rights and Human Responsibility (pp. 69-85). New York, NY: The Viking Press.

Gamborg, C., Gremmen, B., Christiansen, S. B., \& Sandoe, P. (2010). De-domestication: Ethics at the intersection of landscape restoration and animal welfare. Environmental Values, 19(1), 57-78.

Haraway, D. (2008). Value-added dogs and lively capital. In C. Wolfe (Ed.), When Species Meet (pp. 45-68). Minneapolis, MN: University of Minnesota Press.

Haraway, D. J. (2003). The Companion Species Manifesto: Dogs, People, and Significant Otherness (Vol. 1). Chicago, IL: Prickly Paradigm Press.

Hens, K. (2008). Ethical responsibilities towards dogs: An inquiry into the dog-human relationship. Journal of Agricultural and Environmental Ethics, 22(1), 3-14.

Hovorka, A. (2008). Cultural geographies transspecies urban theory: Chickens in an African city. Cultural Geographies, 15, 95-117.

Howell, P. (2012). Between the muzzel and the leash: Dog-walking, discipline and the modern city. In P. Atkins (Ed.), Animal Cities: Beastly Urban Histories (pp. 227-228). Surrey, United Kingdom: Ashgate Publishing.

INEgi. (2005). Conteo de Población y Vivienda. Instituto Nacional de Estadística e Informática.

Jerolmack, C. (2008). How pigeons became rats: The cultural-spatial logic of problem animals. Social Problems, 55(1), 72-94.

Kitala, P., McDermott, J., Kyule, M., Gathuma, J., Perry, B., \& Wandeler, A. (2001). Dog ecology and demography information to support the planning of rabies control in Machakos District, Kenya. Acta Tropica, 78(3), 217-230.

Long, N. (2001). Development Sociology: Actor Perspectives. London, United Kingdom: Routeledge. 
Lord, K., Feinstein, M., Smith, B., \& Coppinger, R. (2012). Variation in reproductive traits of members of the genus Canis with special attention to the domestic dog (Canis familiaris). Behavioural Processes, 92, 131-142.

Malaga-Alba, A. (1962). Factores epidemiológicos que rigen el control de la rabia. Boletín de la Oficina Sanitaria Panamericana, 53(2), 105-114.

Matter, H., \& Daniels, T. (2001). Dog ecology and population biology. In C. MacPherson, F. Meslin, \& A. Wandeler (Eds.), Dogs, Zoonoses and Public Health (pp. 17-62). Cambridge, MA: CABI Publishing.

McGee, R. (2004). Unpacking policy: Actors, knowledge and spaces. In M. Brock \& J. Gaventa (Eds.), Unpacking Policy: Knowledge, Actors and Spaces in Poverty Reduction in Uganda and Nigeria (pp. 1-19). Kampala, Uganda: Fountain Publishers.

Medellín Legorreta, R. (200o). Canis lupus. Vertebrados Superiores Exóticos en México: Diversidad, Distribución y Efectos Potenciales. Informe final SNIBCONABIO proyecto No. Un2o. Universidad Nacional Autónoma de México Instituto de Ecología, México D.F., Mexico.

Morters, M. K., Bharadwaj, S., Whay, H. R., Cleaveland, S., Damriyasa, I. M., \& Wood, J. L. N. (2014). Participatory methods for the assessment of the ownership status of freeroaming dogs in Bali, Indonesia, for disease control and animal welfare. Preventive

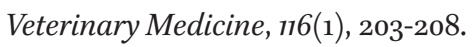

Morters, M. K., Restif, O., Hampson, K., Cleaveland, S., Wood, J. L., \& Conlan, A. J. (2013). Evidence-based control of canine rabies: A critical review of population density reduction. Journal of Animal Ecology, 82(1), 6-14.

oIE (Office International des Epizooties). (2011). Terrestrial Animal Health Code, Chapter 7.7. Stray dog population control.

Ortolani, A., Vernooij, H., \& Coppinger, R. (2009). Ethiopian village dogs: Behavioural responses to a stranger's approach. Applied Animal Behaviour Science, 119(3), 210-218. Philo C., \& Wilbert, C. (200o). Animal Spaces, Beastly Places. London: Routledge.

Power, E. R. (2012). Domestication and the dog: Embodying home. Area, 44(3), 371-378. Real Academia Española. (2017). Diccionario de la lengua española (edición del tricentenario). Retrieved from http://www.rae.es/rae.html.

Ruiz-Izaguirre, E., \& Eilers, C. H. A. M. (2012). Perceptions of village dogs by villagers and tourists in the coastal region of rural Oaxaca, Mexico. Anthrozoös: A Multidisciplinary Journal of the Interactions of People \& Animals, 25(1), 75-91.

Ruiz-Izaguirre, E., Woersem, A., Eilers, K., Wieren, S. E., Bosch, G., Zijpp, A. J., \& Boer, I. J. M. (2014). Roaming characteristics and feeding practices of village dogs scavenging sea-turtle nests. Animal Conservation, 18(2), 146-156. DoI:10.111/acv.12143.

Soi Dog Foundation. (2017). Soi Dog. Retrieved from www.soidog.org.

Srinivasan, K. (2012). The biopolitics of animal being and welfare: Dog control and care in the U K and India (pp. 1-14). In Transactions of the Institute of British Geographers. 
sSA (Secretaría de Salud). (2001). Programa de Acción: Rabia. Technical report. Secretaría de Salud.

SSA (Secretaría de Salud). (2011). Norma Oficial Mexicana NOM-011-SSA2-2011, para la Prevención y Control de la Rabia Humana en los Perros y Gatos. Secretaría de Salud. Steeves, P. H. (2005). Lost dog, or, Levinas faces the animal. In M. Pollock \& C. Rainwater (Eds.), Figuring Animals: Essays on Animal Images in Art, Literature, Philosophy, and Popular Culture (pp. 22-35). New York: Palgrave Macmillan.

Strand, P. (2003). Humane or Insane? The Importation of Foreign Strays into Us Shelters Threatens Health, Sustains 'Overpopulation'. Retrieved from www.naiaonline.org. Valadez-Azúa, R., \& Mestre-Arrioja, G. (1999). Años de oscuridad. In R. V. Azúa (Ed.), Historia del Xoloitzcuintle en México (pp. 99-111). UNAM, Instituto de investigaciones Antropológicas, Museo Dolores Olmedo Patiño, Cámara de Diputados, México, D.F. wно. (1988). Report of wHo Consultation on Dog Ecology Studies Related to Rabies Control, Geneva. World Health Organization.

Wolch, J., \& Emel, J. (1998). Animal geographies: Place, politics, and identity in the nature-culture borderlands. London: Verso.

Young, J. K., Olson, K., Reading, R., Amgalanbaatar, S., \& Berger, J. (2011). Is wildlife going to the dogs? Impacts of feral and free-roaming dogs on wildlife populations. BioScience, 6r(2), 125-132. 